Пантелејмон Хабидис

Georg-August-Universität Göttingen,

Богословски факултет

Аристотелов универзитет у Солуну,

Богословски факултет

pchampides@gmail.com. ${ }^{1}$

DOI: $10.18485 /$ rit.2022.20.37.3
UDK: $271.2-1-051(=14)$

(430)“1874/1875“"

Прегледни рад

Датум пријема: 25.01.2021.

\title{
ДОПРИНОС ГРЧКИХ ТЕОЛОГА НА УНИЈСКИМ КОНФЕРЕНЦИЈАМА У БОНУ 1874. И 1875. ГОДИНЕ
}

\section{Резиме}

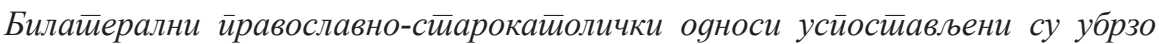
након формалної оснивања зайаgне конфесије 1871. іолине. Насииали су услеg сна-

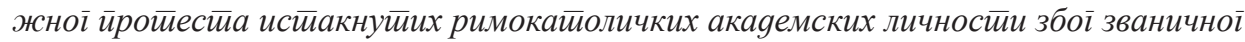
йроїлашења йайске нейойрешивосий. Учестивујући зајеуно са друіим йравославним иеолозима, ірчки иееолози су gали велики gоиринос gвема унијским конферениијама у Бону 1874. и 1875. іооине. Преіоварали су са својим зайадним gелеїаииима и gошли су gо шесии сииавова о исхођењу Светой Духа. Поред йоїа, сайласили су се око неколико иеоолошких учења која су разликовала римокайолицизам оg иравослављь. По-

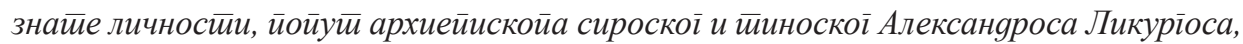

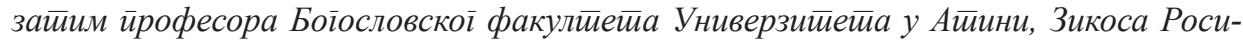
са и Николаоса Дамаласа, йоказали су расииућу динамику новоосноване іррчке gржа-

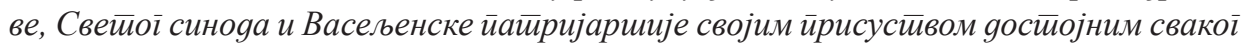
иооитовања и значајан уииицај на сииарокайоличку иееолойју у формирању.

Кључне речи: Бон, Грии, Унија, Православље, Сйарокайоличизам.

\section{Историјски приказ 19. века (западна и источна Европа-Грчка)}

Деветнаести век у западној Европи се сматра временом сукоба. Традиционални принципи, који се често повезују са Римокатоличком црквом и папом, бивају оспоравани и спремни су да уступе место модернизму. Модерно се поистовећује са аутономијом науке и логике у односу на црквене власти. Ова промена се, међутим, није десила одједном. Прво у протестантизму, а касније и у просветитељству, јављају се одређени теолози и филозофи који критикују праксе и учења римокатолицизма - званичне религије

1 Са грчког превео: Obrad Karanović, докторанд на Богословском факултету Аристотеловог универзитета у Солуну, obrad.pbf@gmail.com 
западне Европе. Повратком папе у Рим 1815. године из наполеонског ропства, оживљено је учење о врховној јурисдикцији римског епископа, познато и као ултрамонтанизам. У очима многих верника папа је био победник и жртва. С обзиром на трауматична искуства из периода од 1789-1815. године, свака идеја о независности или отцепљењу државног апарата или римокатоличких универзитета од Цркве изазвала је сумњу у папској курији. Тако је папа Пије IX у свом Силабусу (Syllabus) 1864. осудио индиферентизам (indifferentismus). Сукоб између традиционалног и модерног на Западу је такође изражен кроз контроверзу неотомизма/неосхоластике и такозваног историзма. Неосхоластика је била теолошко уточиште и критеријум „правоверности“ Римске курије, папе и Језуита, односно свих оних који су промовисали ултрамонтанизам у западној Европи. Историзам се развијао у немачкој академској средини, а представљали су га римокатолички теолози који су се противили учењу о папској непогрешивости као већ постојећој доктрини Цркве и врховној власти папе у земљама западне Европе. Најзначајнији теолог 19. века као представник овог мишљења био је Игнац фон Делингер (Ignaz von Döllinger). ${ }^{2}$

Папа Пије IX je 8. децембра 1854. прогласио за догму учење о безгрешном зачећу Дјеве Марије. Десет година касније, енцикликом Quanta cura и Syllabus errorum, припремио је терен за Први ватикански сабор, где је свечано озваничено учење о папској непогрешивости. Рад сабора започео је 8. децембра 1869. Двотрећинска већина - укупно 380 епископа - захтевала је од папе да призна ово учење, док је њих 136 било против. Иако су били у мањини, радило се о личностима од ауторитета које су долазиле из Немачке, Француске, Америке, Аустрије, Мађарске и са Истока. Они су вршили снажну критику и пружали релативно јак отпор. Тако је најважнија антипапска струја тог доба - старокатолицизам - почела да се обликује кроз критике на рачун проглашења догме о беспрекорном зачећу, а успостављена је као покрет и нова конфесија званичним одбацивањем папске непогрешивости. Многи побожни римокатолици, академици и епископи износили су своје аргументе против новоустановљеног учења. ${ }^{3}$ У клими антипапске реакције унутар католицизма, 25. августа 1870. године одржан је Нирнбершки састанак, који је касније довео до оснивања старокатолицизма. Водећи академици и чланови Римокатоличке цркве, као што су Игнац фон Делин-

2 Thomas Albert Howard, The Pope and the Professor, Pius IX, Ignanz von Döllinger, and the Quandary of the Modern Age, Oxford: Oxford University Press, 2017, 20. $51-52$

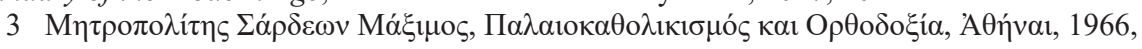


гер, Франц Хајнрих Ројш (Franz Heinrich Reusch), Јохан Фридрих фон Шулте (Johann Friedrich von Schulte) и Јоханес Фридрих (Johannes Friedrich), написали су Нирнбершку декларацију, у складу са којом учењу о папској непогрешивости недостаје утемељење у историји Цркве. ${ }^{4}$

\section{Настанак старокатолицизма 1870-1874.}

Професори из немачких градова Фрајбург, Вроцлав (данас у Пољској), Кобленц, и Келн такође су протестовали због Ватиканског сабора. Два месеца касније, 20. октобра 1870. године, архиепископ Минхена Грегор фон Шер (Gregor von Scherr) позвао је професоре теологије са градског универзитета да преиспитају своје ставове. Делингер и Фридрих су то одбили, што је за последицу имало забрану студентима да похађају њихова предавања, а већ наредне године су били избачени са универзитета. Од тада је изражена жеља за зближавањем западних хришћана са православнима, „источњацима“ или, како су их обично звали „Грцима“. Фридрих је почетком марта 1870. послао писмо Делингеру у Рим, одушевљено предлажући унију са Грчком црквом. ${ }^{5}$ Ова жеља је формално изражена у септембру 1871 . године у Минхену, када су старокатолици, као група одељених антипапских римокатолика, у трећем пасусу изјавили о потреби поновног уједињења са православнима. Присуствовали су јој представници Утрехтске цркве и других протестантских цркава, као и Руси. Минхенски програм обухватао је ставове Нирнбершке декларације и новооснованог Комитета. Овом конференцијом се старокатолицизам одвојио од Римокатоличке цркве, док је истовремено своју пажњу усмерио ка Православној Цркви. ${ }^{6}$

Годину дана касније у Келну је основана комисија која је проучавала начине поновног црквеног уједињења. Чинили су га већ поменути Делингер, Фридрих, Шулте, као и Јосиф Ланген (Joseph Langen) и Јужен Мишод (Eugène Michaud). У својим предавањима у јануару и фебруару 1872. године, Делингер је говорио о светоотачком и традиционалном карактеру Православне Цркве, интензивирајући тако на-

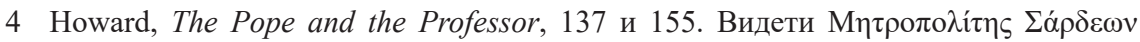

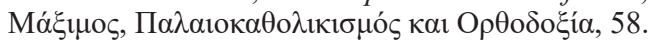

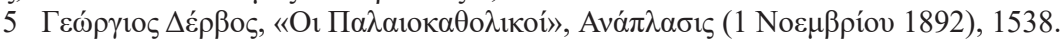

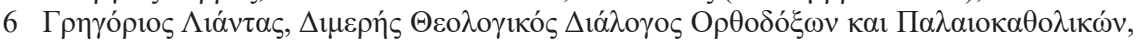

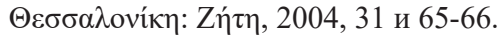


поре зближавања западних и источних хришћана у Европи. ${ }^{7}$ Исте године, од 20. до 22. септембра, архиепископ сироски и тиноски Александрос Ликургос и директор Ризаријеве црквене богословије Сократ Колијацос позвани су на конференцију у Келну, али нису могли да присуствују. Ликургос је поново позван на конференцију у Констанци 1873. У свом писму, написаном на немачком језику, изразио је жељу да учествује, али је на крају био онемогућен. Због тога је Православна Црква била ограничена до следећег састанка заказаног за 1874. годину у Фрајбургу на изасланике руског синода, Јосифа Васиљева и чувеног панслависту Александра Кирјејевског. ${ }^{8}$ Ту се први пут налази грчко присуство из тадашње модерне грчке краљевине. Професор на Ризаријевој црквеној богословији и предавач на Богословском факултету Атинског универзитета Зикос Росис био је представник Православне Цркве Грчке, али уједно и Васељенске патријаршије. ${ }^{9}$

\section{Грчко присуство на конференцијама у Бону}

Од састанка у Фрајбургу па надаље, грчка делегација је активно учествовала у већини састанака, од којих су најважније биле две бонске конференције. Унијске конференције у Бону из 1874. и 1875. чиниле су први званични покушај уједињења англиканаца и старокатолика са православнима; на њима је дошло до дефинисања онога у шта старокатолици верују, али и до кулминирања билатералних - повремених - контаката између Грка и западне Европе. Први пут још од сабора у Ферари и Фиренци (1438-1439), представници Православних Цркава (из Русије, Румуније, Васељенске патријаршије и Аутокефалне Цркве Грчке) и хришћани Запада окупљају се ради поновног уједињења. Одбацивање папског првенства и непогрешивости, истицање вере древне Цркве пре великог раскола 1054. године и жеља за уједињењем хришћана представљали су садржај са којим је Црква Грчке приступала хришћанима Уједињеног Краљевства, Немачке, Холандије, Аустрије и Чешке. 1979,294

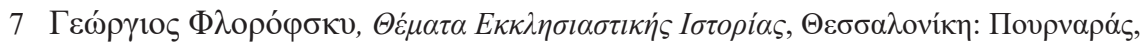

8 John E.B. Mayor (ed.), Report of the Congress of Constance, held September 12th, 13th, 14th, London, Oxfrod and Cambridge: Rivingtons, 1873, 8 и 32.

9 Urs Küry, Die Altkatholische Kirche: Ihre Geschichte, ihre Lehre, ihr Anliegen, Die Kirchen der Welt, Band III, Stuttgart: Evangelisches Verlagswerk Stuttgart, 1966, 57-64. 
Прва унијска конференција у Бону одржана је 14. августа 1874. Председавао је професор Јосиф Рајнкенс (Joseph Hubert Reinkens). Као основна начела конференције промовисани су Символи и учења хришћанске вере првих векова, као и ,јединство у неопходним доктринама“ (,unitas in necessariis“"). ${ }^{10}$ Старокатолици су постали спона између друге две конфесије, након што су успостављене две комисије: старокатолици-англиканци, где су се расправе водиле на енглеском језику у преподневним часовима и старокатолици-православци, где су се разговори водили на немачком језику у поподневним часовима. Франц Хајнрих Ројш (Reusch) је, као ректор Универзитета у Бону, обезбедио неопходно место за састанке, док је Делингер био председавајући. ${ }^{11}$ Зикос Росис отпутовао је у Бон како би учествовао на конференцији $2 / 14$. септембра. Он сведочи и о учешћу четворице православних теолога из Русије и других неправославних из Данске, Француске, Швајцарске и Немачке, као и о свему ономе што се догађало. ${ }^{12}$ Место и улога Светог Писма, као и разна литургијска питања, била су предмет дискусија. На самом почетку, истакнут је значај Светог Писма у хришћанству, уз посебан нагласак да се тиме не потцењује црквена традиција. Формулација старокатоличког епископа Рајнкенса о Библији као делу свештеног предања нарочито је занимљива. Професор Росис је у одређеном тренутку дао одлучујући допринос овом учењу, захтевајући да се јасно дефинише место Библије у Цркви. Западне литургијске праксе, као што је употреба бесквасног хлеба током причешћа и вршење тајне Миропомазања одвојено од Крштења, поменуте су без даље разраде. Међутим, питање евхаристијске епиклезе заокупило је велику пажњу у дијалогу. Чинило се да православни прихватају Делингерову тврдњу да се Дух Свети индиректно призива у Божанској литургији. Међутим, поставили су као предуслов повратак форме пре великог раскола. Западни делегати су направили значајан уступак прихватајући православну праксу светог Јелеосвећења, одбацујући уједно вршење истог на самртном часу. Коначно, обавезни целибат свештенства дошао је на дневни ред, што према Делингеру није требало да буде препрека поновном уједињењу, буду-

10 F. H. Reusch (Hg.), Bericht über die am 14., 15. und 16. September zu Bonn gehaltenen Unions-Conferenzen, Bonn: P. Neusser, 1874, 1.

11 Reusch, Bericht über die am 14., 15. und 16. September zu Bonn gehaltenen UnionsConferenzen, 6.

12 Z $\tilde{\eta} \kappa o \varsigma$ P 
ћи да западна Црква није била заступљена на Пето-шестом васељенском сабору који га је осудио. Ово гледиште наишло је на бурну реакцију православних, који су га окарактерисали као папску иновацију. Сви делегати су се сложили око осуде папске непогрешивости и православног разумевања места римског епископа у Цркви. Учење о исхођењу Светог Духа биће више анализирано тек на следећем састанку 1875. године. ${ }^{13}$

Вероисповести-учеснице поставиле су као заједнички принцип на другој конференцији, одржаној од 10. до 16. августа, признање недељивог хришћанства првих векова. Западни делегати су тежили црквеном јединству у облику евхаристијског међузаједништва и федералне уније. ${ }^{14}$ Међу старокатолицима били су епископ Рајнкенс, затим саветник немачке државе и професор у Минхену, Делингер, професори теологије у Бону Ланген, Ројш и Мензел (Andreas Menzel), профеcop филозофије у Бону Франц Кнуд (Franz P. Knoodt), професор филозофије у Гисену Лутербек (J. А. B. Lutterbeck), у Берну Херцог (Eduard Herzog) и многи други способни лаици и свештенство. Од Англиканаца били су присутни гибралтарски епископ Чарлс Сандфорд (Charles W. Sandford), затим старешина Честера, Џон Ховсон (John S. Howson), пастор цркве Светог Павла, Хенри Лидон (Henry P. Liddon), пастор Фредерик Мејерик (Frederick Meyerick) и други. Међу Американцима су били пастор и доктор теологије Вилијам Лангдон (William Chancey Langdon), затим пастор и секретар епископског синода Хенри Потер (Henry Potter), пастор Вилијам Пери (William S. Perry), пастор Америчке цркве у Риму, Роберт Невин (Robert J. Nevin), професор теологије из Њујорка Филип Шаф (Phillip Schaff) и други клирици. Присуство православних било је динамичније са аргисоским епископом Генадијем, епископом доњег Подунавља Мелхиседеком (Stefamescu) из Румуније, српским архимандритом Савом, професором Богословије у Задру Никодимом Милашем из Далмације и Русима, протојерејем Јанишевим (Johannes Janyschew), професором Осинином (Johann Terentiewitsch Ossinin), Сукотином и Кирјејевским. Посебно треба истаћи немачког професора и преобраћеника у православље Јозефа Џулијана Овербека (Joseph Julian Overbeck), који је представљао руски Синод. Његово

13 Reusch, Bericht über die am 14., 15. und 16. September zu Bonn gehaltenen Unions-

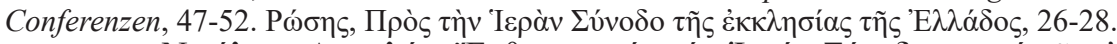

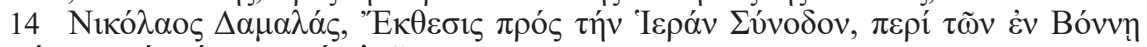

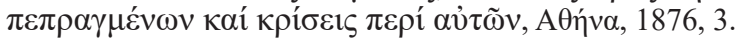


деловање у западној Европи повезано је са оним делом западног православља који се у то време надао да ће се остварити јединство са старокатолицима. Грци су имали запажено присуство у личностима архиепископа Александроса Ликургоса, затим архимандритима Васељен-

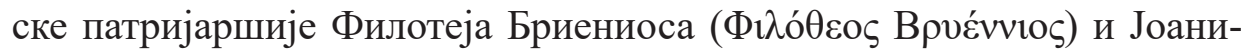
са Анастасиадиса (І $\omega \alpha ́ v v \eta \varsigma ~ A v \alpha \sigma \tau \alpha \sigma i \alpha ́ \delta \eta \varsigma)$, професорима теологије на Атинском универзитету Николасом Дамаласом (Niкó $\lambda \alpha о \varsigma \Delta \alpha \mu \alpha \lambda \alpha \varsigma)$ и Зисисом, са доктором филозофије Димитријем Марулијем, свршеним теологом Атанасијем Папалукасом и са другима. ${ }^{15}$

Упркос чињеници да су у Бону анализиране разне догматске разлике између Англиканаца, Старокатолика и Православаца, Filioque је био и остао камен спотицања. Западни делегати су у почетку прихватили нелегално и неправилно додавање уметка никео-цариградском Символу вере, истичући историјски карактер вере. Неспремност Англиканаца и знатног броја старокатолика да осуде овај каснији додатак као погрешно учење довела је до дипломатских формула. Упорност источних теолога, посебно је довела до следећих одлука:

1. Дух Свети исходи од Оца, који је почетак, извор и узрок божанства.

2. Дух Свети не исходи од Сина, јер у божанству постоји само један принцип и узрок, из којег је произишло све у божанству.

3. Дух Свети исходи од Оца кроз Сина.

4. Дух Свети је слика Сина, који је слика Оца; исходи од Оца и почива у Сину као његова сила.

5. Дух Свети исходи од Оца, али не и Сина, јер је Дух уста божанства, кроз која Логос говори.

6. Дух Свети је посредник између Оца и Сина и повезан је преко Сина са Оцем. ${ }^{16}$

По први пут после 1054. године западни хришћани су прихватили древни Символ вере, чинећи тако корак више ка јединству. Одбачена су и римокатоличка учења о безгрешном зачећу Дјеве Марије и опроштају греха (индулгенције), док је прихваћено православно схватање свете тајне Божанске Евхаристије, молитве за умрле (нешто са чим се нису слагали Англиканци) и покајања. Признавање Библи-

15 Reusch, Bericht über die am 14., 15. und 16. September zu Bonn gehaltenen Unions-

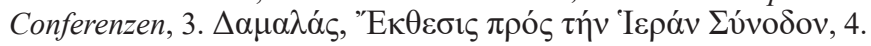

16 Reusch, Bericht über die am 14., 15. und 16. September zu Bonn gehaltenen UnionsConferenzen, 91-93. 
је као првог правила вере, став формулисан 1874. године, морао је бити разјашњен, јер је постојао ризик од двоструког тумачења. С једне стране, православни су је ставили у контекст шире црквене традиције, док су се, с друге, англиканци били ограничили искључиво на њу. Неприхватање Седмог васељенског сабора од стране последњих, као и усвајање теорије о огранцима од стране старокатолика, постављају препреке будућим контактима. ${ }^{17}$

Академски теолог Јоанис Кармирис примећује да су се православни поделили на две струје: на критичаре уније (углавном Грци и Овербек) са старокатолицима и на њене присталице (Русе). Конзервативнија струја је захтевала да западњаци признају пост-расколничке православне синоде, док су либералнији теолози тражили само седам. Према Кармирису, различитост еклисиологијаิ је блокирала пут ка унији. ${ }^{18}$ Своју тезу заснива на извештају Рососа и у потпуности се слаже са Овербековом критиком Die Bonner Unions Konferenzen. На основу ових радова, примећује да је теорија огранака била њихов еклисиолошки положај, будући да су навели да су три цркве (римска, англиканска и православна) део Una Sancta и да се недостаци морају објединити да би се обновила једна Црква. Истовремено, критикује старокатолике због прихватања filioque као теолошког додатка. Они су то сами прихватили као теологумен, будући да то није била званична доктрина цркве. ${ }^{19}$

\section{Закључак}

Грчки теолози 19. века позитивно су допринели напретку билатералних православно-старокатоличких односа. Нарочито је њихово присуство на другој унијској конференцији у Бону 1875. године доказало да је тада слаба новооснована грчка држава са Аутокефалном Грчком Црквом динамично присуствовала међународним збивањима

17 Reusch, Bericht über die am 14., 15. und 16. September zu Bonn gehaltenen UnionsConferenzen, 103-116.

18 Reusch, Bericht über die am 14., 15. und 16. September zu Bonn gehaltenen UnionsConferenzen, 24-27.

19 Julian Joseph Overbeck, Die Bonner Unions-Conferenzen, oder Altkatholicismus und Anglikanismus in ihrem Verhältniss zur Orthodoxie. Eine Appellation an die Patriarchen und Hei-

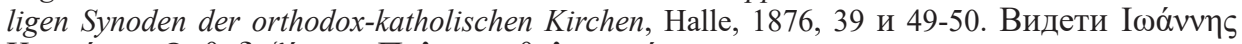

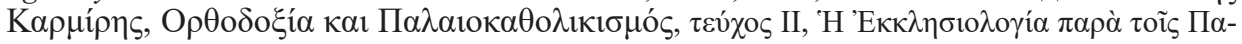

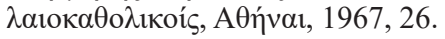


тог времена. У ствари, тако су били у могућности да имају одређени притисак на западне делегате у корист православног учења. На овај начин припремљено је тло за будуће билатералне контакте између двеју страна током 20. века. Рани католички покрет подржао је формирање националних, аутокефалних цркава у западној Европи. Оснивање националних цркава имало је директне политичке последице, усмерене на борбу против ултрамонтанизма, и представљао је изазов из 19. века, а не нешто строго својствено само Балкану. Заједно са Англиканцима, старокатолици су имали за циљ црквену децентрализацију Рима, евентуално имајући као узор православно хришћанство.

\section{Литература}

Howard Thomas Albert, The Pope and the Professor, Pius IX, Ignanz von Döllinger, and the Quandary of the Modern Age, Oxford: Oxford University Press, 2017.

Küry Urs, Die Altkatholische Kirche: Ihre Geschichte, ihre Lehre, ihr Anliegen, Die Kirchen der Welt, Band III, Stuttgart: Evangelisches Verlagswerk Stuttgart, 1966.

Mayor E.B. John (ed.), Report of the Congress of Constance, held September 12th, 13th, 14th, London, Oxfrod and Cambridge: Rivingtons, 1873.

Overbeck Julian Joseph, Die Bonner Unions-Conferenzen, oder Altkatholicismus und Anglikanismus in ihrem Verhältniss zur Orthodoxie. Eine Appellation an die Patriarchen und Heiligen Synoden der orthodox-katholischen Kirchen, Halle, 1876.

Reusch F. H. (Hg.), Bericht über die am 14., 15. und 16. September zu Bonn gehaltenen Unions-Conferenzen, Bonn: P. Neusser, 1874.

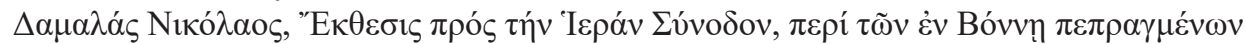

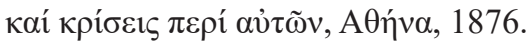

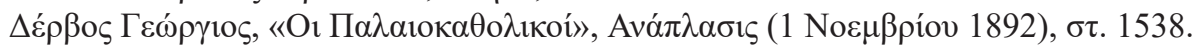

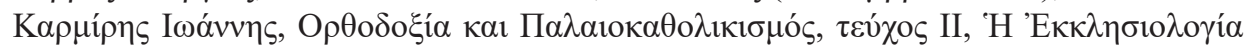

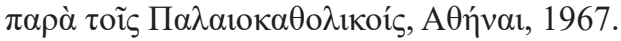

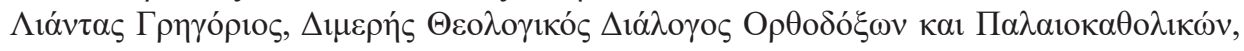

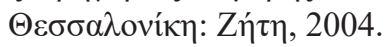

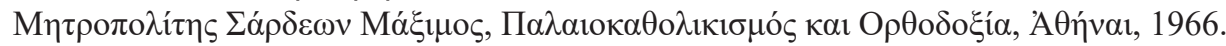

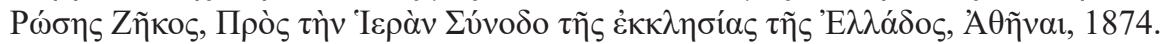

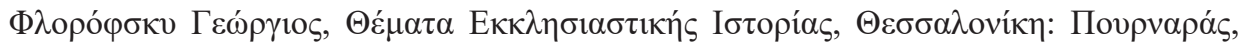
1979. 


\title{
Panteleimon Champidis
}

Georg-August Universität Göttingen, Faculty of Theology

Aristotle University of Thessaloniki, Faculty of Theology

pchampides@gmail.com ${ }^{20}$

\section{CONTRIBUTION OF GREEK THEOLOGISTS TO THE UNION CONFERENCES IN BONN 1874 AND 1875}

\begin{abstract}
Summary
The bilateral Orthodox and Old-Catholic relations began shortly after the formal establishment of the western confession in 1871. It arose out of strong protest by prominent Roman-Catholic academics against the official proclamation of papal infallibility. Although the Greek theologians participated after the Russians, they made the greatest contribution to the two union conferences in Bonn in 1874 and 1875 . They consulted with their western delegates and reached six positions on the procession of the Holy Spirit. In addition, they agreed on several theological teachings that differentiated Roman-Catholicism from Orthodoxy. Figures such as the Archbishop of Syros and Tinos, Alexandros Lykourgos and the professors of the theological school of the University of Athens, Zikos Rossis and Nikolaos Damalas, demonstrated the rising dynamics of the newly established Greek state, the holy synod of the Greek Church and the Ecumenical Patriarchate with their well-respected presence and their significant influence on the emerging Old-Catholic theology.
\end{abstract}

Key words: Bonn, Greeks, Union, Orthodoxy, Old-Catholicism

20 Translated from the Greek: Obrad Karanović, PhD candidate, Faculty of Theology, Aristotle University of Thessaloniki, obrad.pbf@gmail.com 